\title{
Mycobacterium avium subspecies paratuberculosis: A possible causative agent in human morbidity and risk to public health safety
}

\author{
Mary Garvey* \\ Cellular Health and Toxicology Research Group, Institute of Technology, Sligo, Ash Lane, Sligo, Ireland
}

\begin{abstract}
Mycobacterium avium subspecies paratuberculosis is a bacterial parasite and the causative agent of paratuberculosis, a disease predominately found in cattle and sheep. Infection with this microorganism results in substantial farming economic losses and animal morbidity. The link between infection with this pathogen and human disease has been theorised for many years with Crohn's disease being one of many suspected resultant conditions. Mycobacterium avium may be spread from animal to human hosts by water and foodborne transmission routes, where the foodborne route of exposure represents a significant risk for susceptible populations, namely children and the immunecompromised. Following colonisation of the host, the parasitic organism evades the host immune system by use of molecular mimicry, displaying peptide sequences similar to that of the host cells causing a disruption of self-verses non self-recognition. Theoretically, this failure to recognise the invading organism as distinct from host cells may result in numerous autoimmune conditions. Here, the author presents current information assessing the link between numerous diseases states in humans such inflammatory bowel disease, Type 1 diabetes, rheumatoid arthritis, Hashimotol's thyroiditis, multiple sclerosis and autism following infection with Mycobacterium avium paratuberculosis. The possibility of zoonotic transmission of the organism and its significant risk to public health safety as a consequence is also discussed.
\end{abstract}

Keywords: Auto-immune, Human morbidity, Mycobacterium paratuberculosis, Public health, Zoonotic.

\section{Introduction}

Mycobacterium avium subspecies paratuberculosis (MAP) is the causative agent of paratuberculosis (paraTB) (Malvisi et al., 2016) or Johne's disease (JD) in cattle, a chronic granulomatous gastroenteritis. MAP is an obligate intracellular parasite of animals (Grant, 2005); where it can only reproduce within a host cell (in this case a macrophage) of a susceptible species and is unable to reproduce outside of this cellular environment.

Johne and Frothingham first identified MAP as the bacterial pathogen responsible for chronic gastroenteritis of bovine species in 1895, since then its significance as a potential zoonotic pathogen has become increasingly evident. MAP can frequently be found in dairy cattle where it results in significant economic losses due to persistent contagious infection and animal morbidity (Khol et al., 2017).

ParaTB is endemic worldwide occurring frequently in ruminants such as cattle, sheep, goats, and farmed deer. The disease has also been reported in non-ruminants such as wild rabbits, foxes and stoats (Whittington and Sergeant, 2001). Due to the disseminated nature of the pathogen, infected livestock regularly shed the organism in their faeces, milk, and colostrum, resulting in faecal-oral transmission which is considered the primary route of infection (Khol et al., 2017).
At present there is no effective cure for JD and efforts to develop an effective vaccine for MAP have resulted in the commercialisation of Mycopar ${ }^{\circledR}$ which contains inactivated MAP and an adjuvant (Ganusov et al., 2015). The vaccine however, has some side effects and its effectiveness remains unknown, with some studies reporting limited success (Harris and Barletta, 2001) while others report some protection against JD (Knust et al., 2013). The use of vaccines has been a hugely effective tool for controlling the rate of other infectious diseases in humans and animals. An effective MAP vaccine would reduce clinical disease prevalence, improve animal welfare and reduce financial losses to the agricultural industry due to animals culled and poor weight gains.

The aim of this review is to linking the role of this bacterial species in human morbidity. Understanding the health implications of human infection with MAP is of paramount importance, as it is essential to determine its link to chronic debilitating conditions, namely autoimmune diseases such as inflammatory bowel disease (IBD) as either causation or merely correlation.

\section{Routes of transmission of MAP}

Typically the transmission of any pathogenic species to humans may be from one of three general routes, depending on the life cycle and environmental 
survivability of the organisms. MAP is predominately an intestinal parasite of numerous species which is capable of surviving for long periods of time in harsh conditions outside of its host environment. To date, published literature has focused on routes of transmission relating to waterborne (Whiley et al., 2012), food (Roberston et al., 2017) and zoonotic exposure (Wynne et al., 2011).

\section{Waterborne transmission}

The extensive shedding of this microbial species by numerous and various animal hosts suggests that large quantities of viable and potentially infectious bacteria are present in the environment at any given time. Studies have shown that clinically and sub-clinically infected animals can shed MAP in variable numbers into the environment in their faeces, depending on the infected host, the pathogen strain and the manifestations of the disease (Rhodes et al., 2014). Furthermore, the organism can survive for extended periods of time in agricultural slurry, run off and consequently in the wider environment where it exists as either a vegetative state or spheroplast (McNees et al., 2015).

Pickup et al. (2005) reported a $32.3 \%$ detection rate of MAP in freshwaters receiving runoff from farming and domestic locations in South Wales. Waterborne transmission is therefore an inevitability following contamination of surface waters including lakes and rivers (Waddell et al., 2016) with a potential for drinking water contamination as a result. MAP DNA was detected in over $80 \%$ of domestic water samples in Ohio USA (Sechi and Dow, 2015). Studies have shown that MAP is highly resistant to standard water disinfection methods (Naser et al., 2014). Norton et al. (2004) reported up to 103 colony forming units (CFU) of planktonic MAC per $100 \mathrm{ml}$ of potable water, with biofilm samples taken straight from water distribution pipes containing MAC counts up to $106 \mathrm{CFU} / 100 \mathrm{ml}$ (Schulze-Robbecke et al., 1992). Biofilm or sessile communities are notoriously difficult to eradicate and are extremely resistant to chemical disinfection techniques (Garvey et al., 2015). Biofilm organisms in water piping networks can pass in to domestic water and be aerosolised by the tap outlets (Whiley et al., 2012) where there is a potential for human exposure as reported by Zhou (2007). MAP was detected by qPCR (by amplifying the $I S 900$ gene) in approximately $90 \%$ of both water and biofilm samples from 31 cold water faucets in southwestern Ohio (Gill et al., 2011). Additionally, studies by George et al. (1980) have demonstrated that MAC can survive and proliferate in temperatures ranging from 15 to $45^{\circ} \mathrm{C}$ and salinities from 0 to $2 \%$ sodium chloride $(\mathrm{NaCl})$. Nonetheless, the link between water contamination, survival of the organism in treated potable water supplies and human infection has not been extensively investigated.

\section{Foodborne transmission}

The excretion of MAP in both milk and faeces by dairy cows with clinical and subclinical JD (Grant et al., 2015) results in foodborne transmission. It has also been suggested that meat from old dairy cows used for human consumption may be an additional source of infection as it can become concentrated in tissues remote from the intestinal tract and lymph nodes (Gill et al., 2011).

A review by Waddell et al. (2016) summarises several studies which demonstrate MAP detection on meat from animals showing clinical JD and/or positive for M. paratuberculosis by ELISA, PCR or culture (Waddell et al., 2016). A study by Mutharia et al. (2010) reports a $1000 \mathrm{cfu} / \mathrm{g}$ recovery of MAP from 7 of 15 liver, mesenteric and ileocaecal lymph node samples, with smaller numbers isolated from 5 of 15 kidney, superficial inguinal and prescapular lymph node samples (Mutharia et al., 2010). Research has shown that pasteurisation, heating milk to $72^{\circ} \mathrm{C}$ for 15 seconds, is not effective for inactivating MAP (Grant $e t$ al., 2015).

Wynee et al., 2011 reports on a study of 567 pasteurised milk samples from the UK where $11.8 \%$ were MAP positive by PCR analysis and that MAP could be cultured from $1.8 \%$ of samples (Wynne et al., 2011). Additionally, Botsaris et al. (2016) reports the presence of MAP in powdered infant formula using phage amplification coupled with a polymerase chain reaction (PCR) assay, which suggests that freeze drying may be insufficient to remove the pathogen especially in situations of bacterial clumping. A recent study reported testing infant formula for MAP in 65 samples from 18 countries, with greater than $40 \%$ testing positive for viable MAP (Grant et al., 2015). The presence of MAP in a dairy herd is controlled by culling of the herd with subclinical infection and improving calf management (Dore et al., 2012) as transmission via the colostrum is likely. However, the culture of MAP from the milk sourced from asymptomatic cows (Naser et al., 2014) indicates that the spread of MAP is not effectively controlled by these methods.

Additionally, the isolation of MAP from samples containing a mixed variety of microbial species which may outgrow or inhibit it (Roberston et al., 2017) leads to issues when attempting to culture viable numbers. In order to efficiently control the presence of the pathogen in food supplies, better detection methods must be established.

Recent studies have focused on the use of PCR methods with varied success rates due to the presence on PCR inhibitory substances in the food itself (Acharya et al., 2017). Additionally, PCR methods detect DNA of target species and are not a direct indication of viability, in order to determine viable numbers present culture methods must be employed. 


\section{Zoonotic transmission}

At present the MAP species is not recognised as a zoonotic pathogen (Whiley et al., 2012), however the economic losses and animal health issues which occur due to JD coupled with the familiarity of the disease to IBD means that the possibility of zoonotic transmission must not be overlooked. Waddell et al. (2008) concluded that although the evidence supporting the zoonotic transmission of MAP is not strong it cannot be ignored. More recently the publication of Dore et al. (2012) concluded that direct contact with animal faeces is the most likely route of zoonotic transmission of MAP with calves faeces, the housing environment, colostrum, milk (Dore et al., 2012) and grazing (McNees et al., 2015) all listed as potential risk factors. A major concern for the zoonotic transmission of MAP is that MAP-infected animals, such as cattle, remain asymptomatic in a lengthy subclinical phase (Naser et al., 2014) where they may potentially transmit the parasite to humans via contact with excreted faeces and/or milk (Sweeney, 1996).

\section{MAP and human morbidity}

The relationship between human morbidity and infection with Mycobacterium avium paratuberculosis is one of significant importance as more and more researchers try to understand and establish a causative agent behind what are currently classified as autoimmune diseases in humans. Epitope mimicry is the term used to describe the mechanism by which an infectious agent has epitopes which are so similar to the self-antigenic determinants of the host (Bitti et al., 2012), that they result in cross reactivity of the immune system, host cells and the infective agent. This cross reactivity may then result in disease states which are classified as autoimmune conditions. Furthermore, it is generally accepted that autoimmune disorders are a result of environmental triggers in genetically susceptible individuals (Miller, 2011). MAP is one such organism having developed similar epitopes to human host cells as a means of evading the innate immune response (Dow, 2012) and may be an environmental trigger associated with the following conditions.

\section{Johne's Disease and IBD}

As previously stated JD in a chronic, contagious, granulomatous, inflammatory disease (Souriau et al., 2017) affecting numerous animal species resulting from an infection of the gastrointestinal tract (GIT) with Mycobacterium paratuberculosis. Colonisation of the GIT with MAP leads to manifestations of the disease affecting the integrity of the intestinal wall causing oedematous (Tiwari et al., 2006) and weight loss which can ultimately lead to death of the animal. Histologically, infection is evident as the extensive formation of submucosal granulomas and a thickened intestinal wall (Arsenault et al., 2014) resulting in cachexia due to an inability to absorb nutrients.
Infection with MAP has an incubation period which can last from 2 to 6 years (Malvisi et al., 2016) where no signs of infection are seen, progression from this subclinical form to the symptomatic clinical form results in the disease state JD. After infection has occurred, mycobacteria remain hidden in the intestine or associated lymph nodes, predominately in macrophages and payers patches (Tiwari et al., 2006). Once infected intestinal macrophages have lysed, mycobacteria distribute to different sites such as the uterus, the mammary gland or the immune foetus (Mercier et al., 2016).

Post MAP subclinical infection, a cellular immune response is activated causing an influx of mononuclear inflammatory cells. With progression to the clinical stage the humoral immune response is initiated leading a production of MAP-specific antibodies (Ganusov et al., 2015) which can be detected via ELISA specific antibody testing. In human patients with IBD such as ulcerative colitis (UC) and Crohn's disease (CD), the appearance of the gut wall is similar to that seen in animals with JD (Gill et al., 2011).

Furthermore, Crohn's disease is also a chronic, granulomatous inflammatory disease which primarily affects the terminal ileum and colon (Thia et al., 2010) resulting in intestinal lesions, diarrhoea, chronic pain and malnutrition. As with bovine species, the intestinal lesions manifest from continual stimulation of the mucosal and systemic immune systems that prolong the inflammatory cascade (Rubery, 2002).

The cellular response may increase the permeability of the intestinal wall and the entry of MAP into the systemic circulatory systems of the host; studies have described culturing MAP from $50 \%$ of patients with CD (Naser et al., 2004). Furthermore, reports have shown the presence of MAP in breast milk samples from Crohn's patients (Grant et al., 2015) suggesting a possible route of transmission in familial cases of IBD. Genetic similarities between patients with IBD and cattle with JD have been described, for example the NOD2 mutation was found to be more frequent in both ruminant and human cases of infection (Kuenstner et al., 2015).

Studies report that this gene is directly involved with recognition of bacterial cell wall peptidoglycans, activating the nuclear factor immune pathway (Girardin et al., 2003) and in the direct killing of intracellular organisms (Grant, 2005). The identification of this genetic link in both diseases strongly suggests a common causative agent, however one cannot ignore the possibility that the presence of this mutation in Crohn's patients merely leads to an increased risk of MAP infection.

Zamani et al. (2017) concluded that there was a lack of detectable MAP by both ELISA and PCR in non-IBD control individuals (Zamani et al., 2017) compared to 
IBD patients. Additionally, Jeyanathan et al. (2007) reports the visualisation of MAP in $60 \%$ of CD and 40 $\%$ of UC patient tissue samples using oil immersion microscopy. A study examining ileocolonic mucosal biopsies from CD patients for MAP DNA using PCR specific primers showed that $92 \%$ of samples were positive for the presence of MAP compared to the control which had 26\% (Bull et al., 2003).

In Iceland, JD incidence increased from $0 \%$ to $30 \%$ over an 18-year period after introduction of MAPinfected sheep into the local sheep population in 1938 (Fridriksdottir et al., 2000). Research has correlated this with a study reporting increased IBD incidence in Iceland occurring over a combined period of 40 years from 1950 (Gitlin et al., 2012).

Arguments against MAP as a causative agent of IBD relate to the lack of culturable isolates from IBD patients, matching the requirements of Koch's postulates. Studies have shown however, that it is extremely difficult to grow MAP from human samples where MAP exists with a modified cell wall making it resistant to standard identity staining techniques (Sechi et al., 2005) couple with specific growth requirements such as certain levels of iron which it sources from its hosts (Naser et al., 2014). Additionally, JD does not display some of the manifestations of CD such as the segmental localization and features such as fistula, fissures, bleeding, stenosis, adhesions, perforation and the formation of abscesses (Liverani et al., 2014).

In order to prove without a doubt that MAP causes IBD, live organisms must be isolated and cultured from a patient and shown to be able to infect and cause morbidity in a second host. The difficulty relating to this stems from culture techniques and the ethical implications of host infection. However, research by Van Kruiningen et al. (1986) achieved this when they isolated and cultured MAP from a CD patient which subsequently then caused terminal ileitis in goats 5 months post infection.

\section{Resistance to treatment}

As a member of the M. avium complex MAP is typically hard to treat with standard antibiotics (McNees et al., 2015). Additionally, when infecting humans MAP is present without a cell wall, meaning that treatment with antibiotic drugs targeting the bacterial cell wall is unlikely to be effective for this intracellular parasite (Alcedo et al., 2016). Therefore, therapeutics which target peptidoglycan biosynthesis (e.g. penicillin's, cephalosporin's and vancomycin), which is unique to bacteria, are ineffective against Mycobacterium (Dubuisson et al., 2010). Furthermore, the use of such antibiotics may also lead to complications by inhibiting the gut micro-flora and contributing to multidrug resistant bacteria (Naser et al., 2004). Other factors such as an extremely slow growth rate and an inactive dormant stage outside of the host also make MAP difficult to treat with antimicrobials. For the treatment of mycobacterial infections a combination of antimicrobial therapeutics are used to improve efficacy and to limit the development of drug resistance. Typically, the antimicrobial combinations used are macrolide protein synthesis inhibitors such as clarithromycin and azithromycin combined with ethambutol affecting cell metabolism and a rifamycin which inhibits RNA synthesis. At present, there is no long term in vitro infection model for testing the efficacy of antimicrobials against MAP infections.

\section{Antibiotic treatment of IBD}

The successful treatment of CD patients with antibiotic therapy and subsequent remission of the disease in these patients further supports the role of MAP in IBD. Table (1) summarises the drug therapy used, studied and implemented in the treatment of IBD.

\section{Type 1 diabetes}

Type 1 diabetes (T1D) is an autoimmune disease characterised by destruction of the insulin producing cells of the islets of Langerhans by misguided $\mathrm{T}$ cells, specifically autoimmunity towards heat shock protein (HSP) 60, insulinoma - associated protein-2 (IA-2) and glutamic acid decarboxylase (GAD) present on cells within the pancreas (Rani et al., 2010). Although genetic factors are known to be involved in the pathogenesis of T1D there is also evidence suggesting a role of environmental factors such as viruses in the incidence of disease (Naser et al., 2014). Additionally, studies are looking at the role of MAP in cases of T1D, where there is increasing evidence of shared genetic susceptibility between T1D and MAP infections (Rani et al., 2010).

Genetic similarities (Table 2) which have been found relate to the SLC11A1 gene (formerly the NRAMP1 gene) which codes for a membrane protein of monocytes and macrophages (Paccagnini et al., 2009). Mutations in this gene lead to malfunction of the protein and a lack of phagocytosis of the pathogen. Consequently infectious agents can avoid the host immune response and proliferative in vivo. Research studies have isolated MAP DNA from the blood of $63 \%$ of Sardinian T1D patients, but only $16 \%$ of healthy controls (Bitti et al., 2012). Furthermore, the MAP envelope protein was detected in the blood of $47 \%$ Sardinian T1D patients, but in only $8 \%$ of type 2 diabetes (T2D) patients and $13 \%$ of non-diabetic controls (Rosu et al., 2009). GAD65 is expressed in human pancreatic islets cells and has similar amino acid sequences to mycobacterial HSP 65, cross reactivity between both molecules occurs causing destruction of the islet cells. Additionally, HSPs are produced by both human and bacteria cells in response to environmental stresses, where they provide a protective function aiding in cell survival (Dow and Sechi, 2011). These 
HSPs share sequence similarities and therefore can result in a cross reactivity between the human and microbial cells where the immune system fails to differentiate between the two. This cross reactivity and epitope homology between bacterial and human HSPs and GAD65 and bacterial HSP 65 can ultimately lead to destruction of the human cells (Dow and Sechi, 2011) causing issues with insulin production and finally, diabetes in the host. Furthermore, studies have reported that up to 70 percent of T1D patients have antibodies to GAD 65, compared to 4 percent of healthy individuals (Rani et al., 2010). More recently autoantibodies against the islets have been supported by detection of antibodies against the $\beta$-cell antigen zinc transporter 8 (ZnT8) on cell membranes which displays similarities to a MAP protein (MAP3865c) (Masala $e t$ al., 2015).

\section{Rheumatoid arthritis and Hashimoto's thyroiditis}

Rheumatoid arthritis (RA) is an autoimmune condition affecting the peripheral joints in a symmetrical fashion, resulting in chronic inflammation, joint erosion and pain (Peters et al., 2007). Recent studies have identified a role of the SLC11A1 gene in different autoimmune diseases such as RA, juvenile rheumatoid arthritis and multiple sclerosis (MS) (Paccagnini et al., 2009). Mycobacterial HSP65 has also been implicated in human mycobacterial infection, where it is estimated that up to $40 \%$ of the T-cell response is directed against this single protein. Immune responses to mycobacterial HSP65 have been identified in autoimmune disease such as RA and Hashimoto's thyroiditis (Dow, 2012). Yang et al. (2000) reports on the role of NRAMP1 gene polymorphisms in patient susceptibility to RA (Yang et al., 2000). Hashimoto's thyroiditis (HT), chronic lymphocytic thyroiditis or autoimmune thyroiditis results from immune cells attacking the thyroid gland. Studies have reported MAP as an agent in HT based on the same molecular mimicry principle as MAP and T1D (D'Amore et al., 2010) specifically cross reactivity with $\mathrm{ZnT}$. While $\mathrm{ZnT}$ 8 is predominantly expressed in pancreatic islet cells, it is also expressed in the follicular and para-follicular epithelial cells of the thyroid gland (Sechi and Dow, 2015).

\section{Multiple Sclerosis and Autism}

Multiple sclerosis (MS) is a neurodegenerative disorder affecting the central nervous system (CNS) and is classified as an autoimmune disease resulting from genetic and environmental influences. The disease manifests as a loss of the protective myelin sheaths surrounding the axons of neurons within the CNS, leading to inflammatory demyelination due to specific CD4 T cells which attack the myelin sheaths (Cossu et al., 2017). Sardinia in Italy has the highest incidence of autoimmune MS, with MAP being detected in $42 \%$ of MS patients, but only in $6.3 \%$ of healthy controls in one study (Cossu et al., 2011).
An increase in MS has been reported in Iceland from the 1950s as seen with the increase in IBD following the introduction of infected sheep. Remarkably, this geographically secluded island was paratuberculosis free until 1938 (Cossu et al., 2013) suggesting exposure to MAP a possible environmental factor leading to the MS outbreak. The studies of Frau et al. (2016) hypothesize that both genetic and MAP have an independent role in conferring MS risk. Whilst Cusco et al., 2017 concluded that the role of mycobacteria in the initiation and progression of MS could be a population-specific occurrence, reliant on different genetic and non-genetic factors (Cusco et al., 2017). Autism is a neurodevelopmental disorder which manifests in the early stages of childhood, typically identified in affected individuals by three years of age. This condition is predominately recognised by impaired communication, social interaction and behavioural issues (Singh, 2001). Autism spectrum disorders (ASD) are a collection of developmental neurobehavioral conditions that include autistic disorder, Asperger's disorder, and pervasive developmental disorder (Dow, 2012). ASD is predominately a heritable disorder with estimates as high as 80-90\% (Mahajan and Mostofsky, 2015). Epidemiologic studies suggest that some cases of autism can be attributed to environmental factors such as toxic exposures, teratogens, perinatal insults, and prenatal infections such as rubella and cytomegalovirus (Muhle et al., 2004). The link between autoimmune dysfunction and neurodevelopmental diseases such as ASD has been hypothesised based on immunological abnormalities found in autistic patients, but remains unproven (Jung et al., 2011). Specifically, autoimmunity to brain tissue antigens has been recognised in autistic patients with the most common being the CNS myelin-derived myelin basic protein (MBP) (Dow, 2012) and neuron-axon filament proteins (NAFP). Nerve cell myelination is one of the most important postnatal developmental events (Stiles and Jernigan, 2010); therefore, it can be assumed that autoimmunity targeting this process will have huge impact on affected individuals. Studies report an altered blood brain barrier in ASD patient resulting from neurological inflammation, immune dysregulation and increased cytokines in the brain (Samsam et al., 2014). The research of Mameli et al. (2014) reports cross reactivity between MBP and MAP epitopes due to molecular mimicry in MS patients. To date no such studies have been reported on ASD patients, but represents an interesting hypothesis where MAP and MBP cross reactivity may play a role in developing autoimmune ASD. Strength is given to the theory that autism is an autoimmune condition by the fact that many autistic patients respond positively to treatment with immune modulating drugs (Singh, 2001). 
Table 1. Summary of drug therapy and combinations used for the treatment of IBD.

\begin{tabular}{|c|c|c|c|c|c|}
\hline \multicolumn{2}{|c|}{ Drug type } & Target effect & $\begin{array}{l}\text { Disease } \\
\text { condition }\end{array}$ & Effective & Reference \\
\hline \multirow{4}{*}{ Antimicrobials } & $\begin{array}{l}\text { Penicillin's, } \\
\text { Cephalosporin's } \\
\text { Vancomycin }\end{array}$ & $\begin{array}{l}\text { peptidoglycan } \\
\text { biosynthesis - cell } \\
\text { wall inhibition }\end{array}$ & IBD & No & \multirow{4}{*}{$\begin{array}{l}\text { Alcedo et al., } 2016 \\
\text { Dubuisson } \text { et al., } \\
2010\end{array}$} \\
\hline & $\begin{array}{l}\text { Clarithromycin } \\
\text { Azithromycin }\end{array}$ & $\begin{array}{l}\text { macrolide protein } \\
\text { synthesis inhibitors }\end{array}$ & IBD & Yes & \\
\hline & Ethambutol & cell metabolism & IBD & Yes & \\
\hline & Rifamycin & $\begin{array}{l}\text { inhibits RNA } \\
\text { synthesis }\end{array}$ & IBD & Yes & \\
\hline Antimicrobials & $\begin{array}{l}\text { Ciprofloxacin } \\
\text { Fluoroquinolone }\end{array}$ & $\begin{array}{l}\text { inhibition of DNA } \\
\text { gyrase }\end{array}$ & $\mathrm{CD}$ & Varied results & $\begin{array}{l}\text { Lal and Steinhart, } \\
2006\end{array}$ \\
\hline Anti-parasitic & Metronidazole & $\begin{array}{l}\text { inhibits nucleic acid } \\
\text { synthesis }\end{array}$ & $\mathrm{CD}$ & $\begin{array}{l}47 \% \text { remission } \\
\text { rate in patients }\end{array}$ & Prantera et al., 1996 \\
\hline Steroid & Methylprednisolone & Anti-inflammatory & $\mathrm{CD}$ & $\begin{array}{l}68 \% \text { remission } \\
\text { of patients }\end{array}$ & Prantera et al., 1996 \\
\hline $\begin{array}{l}\text { Steroid and } \\
\text { antimicrobial } \\
\text { combination }\end{array}$ & $\begin{array}{l}\text { Clarithromycin } \\
\text { Rifabutin, } \\
\text { Clofazimine and } \\
\text { 16-week course of } \\
\text { corticosteroids }\end{array}$ & $\begin{array}{l}\text { Antimicrobial } \\
\text { Anti-inflammatory }\end{array}$ & $\mathrm{CD}$ & Yes & Selby et al., 2007 \\
\hline Antimicrobial & $\begin{array}{l}\text { Clarithromycin, } \\
\text { Rifabutin, } \\
\text { Ciprofloxacin, } \\
\text { UVBI therapy and } \\
\text { Clofazimine }\end{array}$ & Antimicrobial & $\mathrm{CD}$ & Yes & $\begin{array}{l}\text { Kuenstner } \text { et al., } \\
2015\end{array}$ \\
\hline
\end{tabular}

Table 2. Outlining genetic and epitope similarities between MAP and host cells and their relationship autoimmune conditions.

\begin{tabular}{|c|c|c|c|}
\hline Gene affected & Function & Disease state & Reference \\
\hline NOD2 mutation & $\begin{array}{l}\text { Recognition of bacterial cell } \\
\text { wall peptidoglycans, activating } \\
\text { the nuclear factor immune } \\
\text { pathway, in the direct killing of } \\
\text { intracellular organisms }\end{array}$ & $\begin{array}{l}\text { Johne's Disease } \\
\text { Inflammatory Bowel Disease }\end{array}$ & $\begin{array}{l}\text { Kuenstner } \text { et al., } 2015 \\
\text { Zamani } \text { et al., } 2017 \\
\text { Girardin } \text { et al., } 2003\end{array}$ \\
\hline SLC11A1 gene & $\begin{array}{l}\text { Codes for a membrane protein } \\
\text { of monocytes and } \\
\text { macrophages, } \\
\text { glutamic acid decarboxylase } \\
\text { (GAD), heat shock protein } \\
\text { (HSP) } 60 \\
\text { HSP60 }\end{array}$ & $\begin{array}{l}\text { Type } 1 \text { diabetes } \\
\text { Epitope homology between MAP } \\
\text { and human heat shock proteins and } \\
\text { pancreatic GAD may trigger anti- } \\
\text { GAD antibodies that secondarily } \\
\text { destroy the pancreas } \\
R A \text { and Hashimoto's thyroiditis } \\
\text { Cross reactivity with mycobacterial } \\
\text { HS65 }\end{array}$ & $\begin{array}{l}\text { Paccagnini et al., } 2009 \\
\text { Dow and Sechi, } 2011 \\
\text { Dow, } 2012 \\
\text { Yang et al., } 2000\end{array}$ \\
\hline $\begin{array}{l}\beta \text {-cell antigen zinc } \\
\text { transporter } 8 \text { (ZnT8) }\end{array}$ & $\begin{array}{l}\text { Zinc transporter present on cell } \\
\text { membranes of the pancreas } \\
\text { which displays similarities to a } \\
\text { MAP protein MAP3865c } \\
\text { Present on follicular and para- } \\
\text { follicular epithelial cells of the } \\
\text { thyroid gland }\end{array}$ & $\begin{array}{l}\text { Hashimoto's thyroiditis } \\
\text { Cross reactivity with MAP } 3865 \mathrm{c}\end{array}$ & $\begin{array}{l}\text { Masala et al., } 2011 \\
\text { Sechi and Dow, } 2015 \\
\text { D'Amore } \text { et al., } 2010\end{array}$ \\
\hline $\begin{array}{l}\text { CNS myelin-derived } \\
\text { myelin basic protein } \\
\text { (MBP) } \\
\text { Neuron-axon filament } \\
\text { proteins (NAFP) }\end{array}$ & $\begin{array}{l}\text { Component of the neuronal } \\
\text { cytoskeleton }\end{array}$ & $\begin{array}{l}\text { Multiple sclerosis } \\
\text { Autism } \\
\text { Molecular mimicry between MBP, } \\
\text { NAFP and MAP epitopes }\end{array}$ & $\begin{array}{l}\text { Dow, } 2012 \\
\text { Cossu } \text { et al., } 2011 \\
\text { Mameli } \text { et al., } 2014 \\
\text { Cusco et al., } 2017 \\
\text { Singh, } 2001\end{array}$ \\
\hline IS900 gene & $\begin{array}{l}\text { Encodes for p43 insertion } \\
\text { sequence }\end{array}$ & $\begin{array}{l}\text { Detection in patients presenting } \\
\text { with disease states. } \\
\text { Detection in contaminated water } \\
\text { samples }\end{array}$ & Gill et al., 2011 \\
\hline
\end{tabular}




\section{Control measures}

Given the severity of JD in cattle and the severity of the conditions observed in humans it is essential to implement control measures to prevent the environmental spread of this pathogen and to protect public health safety. Control measures to prevent zoonotic outbreaks relate to vigilant monitoring of food products throughout the food production line. Food production must adhere strictly to Good Manufacturing Practice (GMP) and follow the hazard analysis critical control point (HACCP) guide documents. Effective suitable disinfection procedures must be in place from "farm to fork" to prevent contamination of the food chain. The "farm to fork" food safety approach was initiated by the European Food Safety Authority (EFSA) and involves risk assessment, risk management and risk communication measures which are undertaken by all EU member states to protect public health safety. At a farm level proper sewage disposal and control of agricultural runoff is essential including the use of faecal matter as a fertilizer. At an individual level, adequate hand washing and sanitation is also critical. Following the implementation of such measures, epidemiology studies could give an indication of the success rate in reducing the incidence of JD in cattle.

\section{Conclusion}

At present there is a lack of definitive evidence regarding the contribution of MAP to autoimmune diseases such as IBD, diabetes and rheumatoid arthritis from a causation or correlation aspect. Establishing the undisputable link and risk of MAP transfer from animals to humans must therefore be considered an important precautionary action. Determining the zoonotic transfer of this pathogen will allow for a better assessment of safety measures in terms of zoonotic morbidity in humans which will contribute to a better level of public health safety. The economic cost of infected animals particularly in the dairy industry and medical costs of human cases of morbidity is hugely significant, coupled with animal and patient quality of life means that this issue cannot be disregarded until a definitive answer to the question can be found. The presence of epitope homology between human antigens and MAP proteins may initiate cross reactivity and a failure of self and non-self-recognition resulting in autoimmunity. Molecular mimicry which is based on structural similarities between shared amino acid sequences on pathogens and host cells may provide an explanation to pathogen induced autoimmunity. The manifestations of this cross reactivity might then result in one or more of the many autoimmune conditions discussed depending on location, target organs or specifically target cells. Therefore, even though no definite evidence exists, the mycobacterial hypothesis cannot be completely ruled out; MAP may be a plausible infectious agent linked to the inflammatory process of IBD and other autoimmune disorders (Hermon-Taylor, 2002).

\section{Acknowledgements}

Author wishes to express sincere gratitude to Mark Anthony Slattery and Dr Sarah Hehir for their valuable insight and guidance when writing this review.

\section{Conflict of interest}

The authors declare that there is no conflict of interests.

\section{References}

Acharya, K.R., Dhand, N.K., Whittington, R. and Plain, K.M. 2017. Detection of Mycobacterium avium subspecies paratuberculosis in powdered infant formula using IS900 quantitative PCR and liquid culture media. Int. J. Food Microbiol. 257, 1-9.

Alcedo, K.P., Thanigachalam, S. and Naser, S.A. 2016. RHB-104 triple antibiotics combination in culture is bactericidal and should be effective for treatment of Crohn's disease associated with Mycobacterium paratuberculosis. Gut Pathog. 8, 32. doi: 10.1186/s13099-016-0115-3.

Arsenault, R.J., Maattanen, P., Daigle, J., Potter, A., Griebel, P. and Napper, S. 2014. From mouth to macrophage: mechanisms of innate immune subversion by Mycobacterium avium subsp. Paratuberculosis. Vet. Res. 45, 54. doi: 10.1186/1297-9716-45-54.

Bitti, M.L.M., Masala, S., Capasso, F., Rapini, N., Piccinini, S., Angelini, F., Pierantozzi, A., Lidano, R., Pietrosanti, S., Paccagnini, D. and Sechi, L.A. 2012. Mycobacterium avium subsp. paratuberculosis in an Italian Cohort of Type 1 Diabetes Pediatric Patients. Clin. Dev. Immunol. 2012, 785262. doi:10.1155/2012/785262.

Botsaris, G., Swift, B.M.C., Slana, I., Liapi, M., Christodoulou, M., Hatzitofi, M., Christodoulou, V. and Rees, C.E. 2016. Detection of viable Mycobacterium avium subspecies Paratuberculosis in powdered infant formula by phage-PCR and confirmed by culture. Int. J. Food Microbiol. 216, 91-94.

Bull, T.J., McMinn, E.J., Sidi-Boumedine, K., Skull, A., Durkin, D., Neild, P., Rhodes, G., Pickup, R. and Hermon-Taylor, J. 2003. Detection and verification of Mycobacterium avium subsp. Paratuberculosis in fresh ileocolonic mucosal biopsy specimens from individuals with and without Crohn's disease. J. Clin. Microbiol. 41(7), 2915-2923.

Cossu, D., Yokoyama, K. and Hattori, N. 2017. Conflicting Role of Mycobacterium Species in Multiple Sclerosis. Front Neurol. 8, 216.

Cossu, D., Masala, S. and Sechi, L.A. 2013. A Sardinian Map for Multiple Sclerosis. Future Microbiol. 8(2), 223-232. 
Cossu, D., Cocco, E., Paccagnini, D., Masala, S., Ahmed, N., Frau, J., Marrosu, M.G. and Sechi, L.A. 2011. Association of Mycobacterium avium subsp. paratuberculosis with Multiple Sclerosis in Sardinian Patients. PLoS One. 6(4). doi: 10.1371/journal.pone.0018482.

D’Amore, M., Lisi, S., Sisto, M., Cucci, L. and Dow, C.T. 2010. Molecular identification of Mycob7rium avium subspecies paratuberculosis in an Italian patient with Hashimoto'sthyroiditis and Melkersson-Rosenthal syndrome. J. Med. Microbiol. 59(Pt 1), 137-139.

Dore, E., Pare, J., Cote, G., Buczinski, S., Labrecque, O., Roy, J.P. and Fecteau, G. 2012. Risk Factors Associated with Transmission of Mycobacterium avium subsp. paratuberculosis to Calves within Dairy Herd: A Systematic Review. J. Vet. Intern. Med. 26, 32-45.

Dow, C.T. 2012. M. paratuberculosis Heat Shock Protein 65 and Human Diseases: Bridging Infection and Autoimmunity. Autoimmune Dis. 2012, 150824. doi:10.1155/2012/150824.

Dow, C.T. and Sechi, L.A. 2011. Environmental Triggers of Type 1 Diabetes Mellitus Mycobacterium Avium Subspecies Paratuberculosis. Type 1 Diabetes - Pathogenesis, Genetics and Immunotherapy. doi: 10.5772/20614.

Dubuisson, T., Bogatcheva, E., Krishnan, M.Y., Collins, M.T., Einck, L., Nacy, C.A. and Redy, V.M. 2010. In vitro antimicrobial activities of capuramycin analogues against non-tuberculous mycobacteria. J. Antimicrob. Chemother. 65(12), 2590-2597.

Frau, J., Cossu, D., Coghe, G., Lorefice, L., Fenu, G., Melis, M., Paccagnini, D., Sardu, C., Murru, M.R., Tranquilli, S., Marrosu, M.G., Sechi, L.A. and Cocco, E. 2016. Mycobacterium avium subsp. paratuberculosis and multiple sclerosis in Sardinian patients: epidemiology and clinical features. Mult. Scler. 19(11), 1437-1442.

Fridriksdottir, V., Gunnarsson, E., Sigurdarson, S. and Gudmundsdottir, K.B. 2000. Paratuberculosis in Iceland: epidemiology and control measures, past and present. Vet. Microbiol. 77, 263-267.

Ganusov, V.V., Klinkenberg, D., Bakker, D. and Koet, A.P. 2015. Evaluating contribution of the cellular and humoral immune responses to the control of shedding of Mycobacterium avium spp. paratuberculosis in cattle. Vet. Res. 46, 62. doi: 10.1186/s13567-015-0204-1.

Garvey, M., Rabbit, D., Stocca, A. and Rowan, N. 2015. Pulsed Ultraviolet light inactivation of Pseudomonas aeruginosa biofilms. Water Environ. J. 29(1), 36-42.

George, K.L., Parker, B.C., Ruft, H. and Falkinham, J.O. 1980. Epidemiology of infection by nontuberculous mycobacteria. Growth and survival in natural waters. Am. Rev. Respir. Dis. 122, 89-94.

Gill, C.O., Saucier, L., and Meadus, W.J. 2011. Mycobacterium avium subsp. paratuberculosis in Dairy Products, Meat, and Drinking Water. J. Food Prot. 74(3), 480-499.

Girardin, S.E., Boneca, I.G., Carneiro, L.A.M., Antignac, A., Jehanno, M., Viala, J., Tedin, K., Taha, M.K., Labigne, A., Zahringer, U., Coyle, A.J., Distefano, P.S., Sansonetti, P.J. and Philpott, D.J. 2003. Nod1 detects a unique muropeptide from gram-negative bacterial peptidoglycan. Science 300, 1584-1587.

Gitlin, L., Borody, T.J., Chamberlain, W. and Campbell, J. 2012. Mycobacterium avium ss paratuberculosis-associated Diseases Piecing the Crohn's Puzzle Together. J. Clin. Gastroenterol. 46, 649-655.

Grant, I.R. 2005. Zoonotic potential of Mycobacterium avium ssp. paratuberculosis: the current position. J. Appl. Microbiol. 98, 1282-1293.

Grant, I., Foddai, A., Kunkel, B. and Collins, M.T. 2015. Detection of viable Mycobacterium avium subsp.paratuberculosis (MAP) in infant formula. Presented at the $12^{\text {th }}$ International Colloquiumon Paratuberculosis. Parma, Italy.

Harris, N.B. and Barletta, R.G. 2001. Mycobacterium avium subsp. paratuberculosis in Veterinary Medicine. Clin. Microbiol. Rev. 14(3), 489-512.

Hermon-Taylor, J.H. 2002. Treatment with drugs active against Mycobacterium avium subspecies paratuberculosis can heal Crohn's disease: more evidence for a neglected Public Health tragedy. Dig. Liver Dis. 34, 9-12.

Jeyanathan, M., Boutros-Tadros, O., Radhi, J., Semret, M., Bitton, A. and Behr, M.A. 2007. Visualization of Mycobacterium avium in Crohn's tissue by oilimmersion microscopy. Microbes Infect. 9(14-15), 1567-1573.

Jung, J.Y., Kohane, S.I. and Wall, D.P. 2011. Identification of autoimmune gene signatures in autism. Transl. Psychiarty 1(12), e63.

Khol, J.L., Braun, A.L., Slana, I., Kralik, P. and Wittek, T. 2017. Testing of milk replacers for Mycobacterium avium subsp. paratuberculosis by PCR and bacterial culture as a possible source for Johne's disease (paratuberculosis) in calves. Prev. Vet. Med. 144, 53-56.

Knust, B., Patton, E., Ribeiro-Lima, J., Bohn, J.J. and Wells, S.J. 2013. Evaluation of the effects of a killed whole-cell vaccine against Mycobacterium avium subsp paratuberculosis in 3 herds of dairy cattle with natural exposure to the organism. J. Am. Vet. Med. Assoc. 242, 663-669.

Kuenstner, J.T., Chamberlin, W., Nasser, S.A., Collins, M.T., Dow, C.T., Aitken, J.M., Weg, S., Telega, G., 
John, K., Hass, D., Eckstein, T.M., Kali, M., Welch, C. and Petrie, T. 2015. Resolution of Crohn's disease and complex regional pain syndrome following treatment of paratuberculosis. World J. Gastroenterol. 21(13), 4048-4062.

Lal, S. and Steinhart, A.H. 2006. Antibiotic therapy for Crohn's disease: A review. Can. J. Gastroenterol. 20(10), 651-655.

Liverani, E., Scaioli, E., Cardamone, C., Dal Monte, P. and Belluzzi A. 2014. Mycobacterium avium subspecies paratuberculosis in the etiology of Crohn's disease, cause or epiphenomenon? World J. Gastroenterol. 20(36), 13060-13070.

Mahajan, R. and Mostofsky, S.H. 2015. Neuroimaging endophenotypes in autism spectrum disorder. CNS Spectr. 20(4), 412-426.

Malvisi, M., Palazzo, F., Morandi, N., Lazzari, B., Williams, J.L., Pagnacco, G. and Minozzi, G. 2016. Responses of bovine innate immunity to Mycobacterium avium subsp. Paratuberculosis infection revealed by changes in gene expression and levels of microRNA. PLoS One 11(10), e0164461. doi: 10.1371/journal.pone.0164461.

Mameli, G., Cossu, D., Cocco, E., Masala, S., Frau, J., Marrosu, M.G. and Sechi, L.A. 2014. Epstein-Barr virus and Mycobacterium avium subsp. paratuberculosis peptides are cross recognized by anti-myelin basic protein antibodies in multiple sclerosis patients. J. NeuroImmunol. 270, 51-55.

Masala, S., Cossu, D., Piccinini, S., Rapini, N., Mameli, G., Manca, M.L. and Sechi, L.A. 2015. Proinsulin and MAP3865c homologous epitopes are a target of antibody response in new-onset type 1 diabetes children from continental Italy. Paediatr. Diabetes 16(3), 189-195.

Masala, S., Paccagnini, D., Cossu, D., Brezar, V., Pacifico, A., Ahmed, N., Mallone, R. and Sechi, L.A. 2011. Antibodies recognizing Mycobacterium avium paratuberculosis epitopes cross-react with the beta-cell antigen ZnT8 in Sardinian Type 1 diabetic patients. PLoS One 6(10), e26931. doi: 10.1371/journal.pone.0026931.

McNees, A.L., Markesich, D., Zayyani, N.R. and Graham, D.Y. 2015. Mycobacterium paratuberculosis as a cause of Crohn's disease. Expert. Rev. Gastroenterol. Hepatol. 9, 1523-1534.

Miller, F.W. 2011 Environmental agents and autoimmune diseases. Adv. Exp. Med. Biol. 711, 61-81.

Muhle, R., Trentacoste, S.V. and Rapin, I. 2004. The genetics of autism. Pediatr. 113(5), e472-486.

Mutharia, L.M., Klassen, M.D., Fairles, J., Barbut, S. and Gill, C.O. 2010. Mycobacteriumavium ssp. paratuberculosis in muscle: lymphatic and organ tissues from cows with advanced Johne's disease. Int. J. Food Microbiol. 136, 340-344.
Naser, S.A., Sagramsingh, S.R., Naser A.S. and Thanigachalam, S. 2014. Mycobacterium avium subspecies paratuberculosis causes Crohn's disease in some inflammatory bowel disease patients. World J. Gastroenterol. 20(23), 7403-7415.

Naser, S.A., Ghobrial, G., Romero, C. and Valentine, J.F. 2004. Culture of Mycobacterium avium subspecies paratuberculosis from the blood of patients with Crohn's disease. Lancet 364(9439), 1039-1044.

Norton, C.D., LeChevallier, M.W. and Falkinham, J.O. 2004 Survival of Mycobacterium avium in a model distribution system. Water Res. 38, 1457-1466.

Paccagnini, D., Sieswerda, L., Rosu ,V., Masala, S., Pacifico, A., Gazouli, M., Ikonomopoulos, J., Ahmed, N., Zanetti, S. and Sechi, L.A. 2009. Linking chronic infection and autoimmune diseases: Infection with Mycobacterium avium subspecies paratuberculosis, SLC11A1 polymorphism and Type 1 diabetes mellitus. PLoS One. 4(9), e7109. doi: 10.1371/journal.pone.0007109.

Peters, L.C., Jensen, J.R., Borrego, A., Cabrera, W.H.K., Baker, N., Starobinas, N., Ribeiro, O.G., Iban, O.M. and De Franco, M. 2007. Slc11a1 (formerly NRAMP1) gene modulates both acute inflammatory reactions and pristane-induced arthritis in mice. Genes Immun. 8, 51-56.

Pickup, R.W., Rhodes, G., Arnott, S., Sidi-Boumedine, K., Bull, T.J., Weightman, A., Hurley, M. and Hermon-Taylor, J. 2005. Mycobacterium avium ssp. Paratuberculosis in the catchment area and water of the river Taff in South Wales United Kingdom, and its potential relationship to clustering of Crohn's disease cases in the city of Cardiff. Appl. Environ. Microbiol. 71, 2130-2139.

Prantera, C., Zannoni, F., Scribano, M.L., Berto, E., Andreoli, A., Kohn, A. and Luzi, C. 1996. An antibiotic regimen for the treatment of active Crohn's disease: A randomized, controlled clinical trial of metronidazole plus ciprofloxacin. Am. J. Gastroenterol. 91, 328-332.

Rani, P.S., Sechi, L.A. and Ahmed, N. 2010. Mycobacterium avium subsp. paratuberculosis as a trigger of type-1 diabetes: destination Sardinia, or beyond? Gut pathog. 2(1), 1. doi: 10.1186/17574749-2-1.

Rhodes, G., Richardson, H., Hermon-Taylor, J., Weightman, A, Higham, A. and Pickup, R. 2014. Mycobacterium avium Subspecies paratuberculosis: Human Exposure through Environmental and Domestic Aerosols. Pathogens 3(3), 577-595.

Roberston, R.E., Cerf, O., Condron, R.J., Donaghy, J.A., Heggum, C. and Jordan, K. 2017. Review of the controversy over whether or not Mycobacterium 
avium subsp. paratuberculosis poses a food safety risk with pasteurised dairy products. Int. Dairy J. 73, 10-18.

Rosu, V., Ahmed, N., Paccagnini, D., Gerlach, G., Fadda, G., Hasnain, S.E., Zanetti, S. and Sechi, L.A. 2009. Specific immunoassays confirm association of Mycobacterium avium subsp. Paratuberculosis with type- 1 but not type- 2 diabetes mellitus. PLoS One, 4(2), e4386. doi: 10.1371/journal.pone.0004386.

Rubery, E. 2002. A Review of the Evidence for a Link Between Exposure to Mycobacterium paratuberculosis and Crohn's Disease (CD) in Humans. A Report for the Food Standards Agency.

Samsam, M., Ahangari, R. and Naser, S.A. 2014. Pathophysiology of autism spectrum disorders: Revisiting gastrointestinal involvement and immune imbalance. World J. Gastroenterol. 20(29), 9942-9951.

Schulze-Robbecke, R., Janning, B. and Fischeder, R. 1992. Occurrence of mycobacteria in biofilm samples. Tuber. Lung Dis. 73, 141-144.

Sechi, L.A. and Dow, C.T. 2015. Mycobacterium avium ss. paratuberculosis Zoonosis - The Hundred Year War - Beyond Crohn's Disease. Front. Immunol. 6, 96. doi: 10.3389/fimmu.2015.00096.

Sechi, L.A., Scanu, A.M., Molicotti, P., Cannas, S., Mura, M., Dettori, G., Fadda, G. and Zanetti, S. 2005. Detection and Isolation of Mycobacterium avium subspecies paratuberculosis from intestinal mucosal biopsies of patients with and without Crohn's disease in Sardinia. Am. J. Gastroenterol. 100, 1529-1536.

Selby, W., Pavli, P., Crotty, B., Florin, T., RadfordSmith, G., Gibson, P., Mitchell, B., Connell, W., Read, R., Merrett, M., Ee, H. and Hetzel, D. 2007. Two-year combination antibiotic therapy with clarithromycin, rifabutin, and clofazimine for Crohn's disease. Gastroenterol. 132, 2313-2319.

Singh, V.K. 2001. Neuro-immunopathogenesis in autism. NeuroImmune Biol. (1), 447-458.

Souriau, A., Freret, S., Foret, B., Willemsen, P.T.J., Bakker, D. and Guilloteau, L.A. 2017. Identification of new antigen candidates for the early diagnosis of Mycobacterium avium subsp. paratuberculosis infection in goats. Res. Vet. Sci. $115,278-287$.

Stiles, J. and Jernigan, T.L. 2010. The Basics of Brain Development. Neuropsychol. Rev. 20, 327-348.

Sweeney, R.W. 1996. Transmission of paratuberculosis. Vet. Clin. North Am. Food Anim. Pract. 12, 305-312.

Thia, K., Sandborn, W., Harmsen, W., Zinsmeister, A. and Loftus, E., Jr. 2010. Risk factors associated with progression to intestinal complications of Crohn's disease in a population-based cohort. Gastroenterol. 139, 1147-1155.

Tiwari, A., VanLeeuwen, J.A., McKenna, S.L.B., Keefe, G.P. and Barkema, H.W. 2006. Johne's disease in Canada. Part I: Clinical symptoms, pathophysiology, diagnosis, and prevalence in dairy herds. Can. Vet. J. 47, 874-882.

Van Kruiningen, H.J, Chiodini, R.J, Thayer, W.R., Coutu, J.A., Merkal., R.S. and Runnels, P.L. 1986. Experimental disease in infant goats induced by a Mycobacterium isolated from a patient with Crohn's disease. A preliminary report. Dig. Dis. Sci. 31, 1351-1360.

Waddell, L., Raji, A., Stark, K. and McEwen, S.A. 2016. Mycobacterium avium ssp. paratuberculosis detection in animals, food,water and other sources or vehicles of human exposure: A scoping review of the existing evidence. Prev. Vet. Med. 132, 32-48.

Waddell, L.A., Rajić, A., Sargeant, J., Harris, J., Amezcua, R., Downey, L., Read, S. and McEwen, S.A. 2008. The zoonotic potential of Mycobacterium avium spp. paratuberculosis: a systematic review. Can. J. Public Health 99(2), 145155.

Whiley, H., Keegan, A., Giglio, S. and Bentham, R. 2012. Mycobacterium avium complex - the role of potable water in disease transmission. J. Appl. Microbiol. 113(2), 223-232.

Whittington, R.J. and Sergeant, E.S.G. 2001. Progress towards understanding the spread, detection and control of Mycobacterium avium subsp. paratuberculosis in animal populations. Aust. Vet. J. 79, 267-278.

Wynne, J.W., Bull, T.J., Seemann, T., Bulach, D.M., Wagner, J., Kirkwood, C.D. and Michalski, W.P. 2011. Exploring the Zoonotic Potential of Mycobacterium avium Subspecies paratuberculosis through Comparative Genomics. PLoS One 6(7), e22171. doi:10.1371/journal.pone.0022171.

Yang, S.Y., Kim, S.J., Kim, J.W. and Koh, E. 2000. NRAMP1 Gene polymorphisms in patients with Rheumatoid arthritis in Koreans. J. Korean Med. Sci. 15, 83-87.

Zamani, S., Zali, M.R., Aghdaei, H.A., Sechi, A., Niegowska, M., Caggiu, E., Keshavarz, R., Mosavari, N. and Feizabadi, M.M. 2017. Mycobacterium avium subsp. paratuberculosis and associated risk factors for inflammatory bowel disease in Iranian patients. Gut Pathog. 9, 1. doi: 10.1186/s13099-016-0151-z.

Zhou, Y. 2007. Particle size distribution and inhalation dose of shower water under selected operating conditions. Inhal. Toxicol. 19(4), 333-342. 